\title{
PERENCANAAN PENJADWALAN PERAWATAN MESIN WHEEL LOADER DENGAN PENDEKATAN RELIABILITY CENTERED MAINTENANCE DI PT. SWADAYA GRAHA
}

\author{
Muhamat Rizal Abidin ${ }^{1)}$, Said Salim Dahda ${ }^{2}$, Deny Andesta ${ }^{3)}$ \\ ${ }^{1}$ Mahasiswa Teknik Industri, Fakultas Teknik, Universitas Muhammadiyah Gresik \\ ${ }^{2,3}$ Dosen Teknik Industri, Fakultas Teknik, Universitas Muhammadiyah Gresik Jl. Sumatera No. 101 \\ GKB - Gresik 61121 e-mail : rizalabidin1803@gmail.com
}

\begin{abstract}
ABSTRAK
PT Swadaya Graha merupakan anak perusahan dari PT Semen Indonesia Tbk yang merupakan perusahan yang memproduksi semen. Tugas dari PT Swadaya Graha adalah untuk mengelola dan mempelihara alat - alat berat jenis Wheel loader. Permasalahan yang terjadi pada pengelolaan adalah tidak tercapainya rencana jam operasional dari wheel loader dikarenakan waktu downtime yang tinggi dan tidak adanya penjadwalan untuk perawatan mesin wheel loader. Permasalan ini akan di selesaikan menggunakan pendekan Reliability Centered Maintenance (RCM) dengan pengaplikasian dari FMEA untuk mengetahui mode kegagalan dan efek dari kegagalan kemudian menentukan komponen kritis. Logict Tree Analysis digunakan untuk mengategorikan mode kegagalan kebeberapa kategori kemudian pemilihan tindakan atau Task Selection. Setelah itu menentukan interval perawatan dari komponen kritis yang optimal dengan perhitungan Total Minimum Downtime (TMD). Hasil pengolahan data dari FMEA terdapat 28 komponen dari 28 jenis kegagalan. Terdapat 4 komponen yang memiliki nilai RPN tertinggi yaitu yaitu Pump Hydroulic, Block engine, Radiator dan Bostpump. Hasil dari proses RCM penjadwal perawatan dan pemilihan tindakan untuk komponen Pump Hydroulic masuk dalam kategori A (safety problem) dengan pemilihan tindakan yaitu CD/ Conditional Direted dengan perencanaan penjadwalan perawatan 52 hari. Komponen Block Engine masuk dalam kategori B (Outage problem) dengan pemilihan tindakan yaitu CD/ Conditional Direted perencanaan penjadwalan perawatan 58 hari. Komponen Radiator masuk dalam Kategori A (safety problem) dengan pemilihan tindakan yaitu $\mathrm{CD}$ / Conditional Direted perencanaan penjadwalan perawatan 18 hari. Komponen Bostpump masuk dalam kategori B (outage problem) dengan pemilihan tindakan yaitu CD/ Conditional Direted perencanaan penjadwalan perawatan 16 hari.
\end{abstract}

Kata Kunci : komponen kritis, penjadwalan, FMEA, RCM dan TMD.

\section{PENDAHULUAN}

PT. Swadaya Graha merupakan anak usaha PT. Semen Gresik Tbk (persero) yang kini telah bertransformasi menjadi holding company PT. Semen Indonesia Tbk. PT. Swadaya Graha adalah perusahaan yang telah dipercaya untuk mengelola divisi alat-alat berat yang ada di pabrik PT. Semen Indonesia Tbk yang berlokasi di Gresik. Dengan kompetisi persaingan yang semakin ketat dalam dunia industri semen, maka PT. Semen Indonesia Tbk, harus dapat meningkatkan efektivitas dan efesien dalam proses produksi. Salah satunya menuntut PT. Swadaya Graha sebagai pengelola dan pemeliharaan divisi alat - alat berat di pabrik gresik untuk meningkatkan keandalan mesin alat berat seoptimal mungkin dalam mendukung proses produksi. Mesin wheel loader merupakan salah satu alat berat yang beroda karet (ban), dalam dunia pertambangan wheel loader digunakan untuk mengangkut material yang akan dimuat ke dalam dump truck atau digunakan untuk memindahkan material dari suatu tempat ketempat yang lain. Sistem penggerak yang digunakan untuk menggerakakan bucket dalam wheel loader menggunakan sistem hidrolik. Mesin wheel loader yang ada di PT. Semen Indonesia Tbk, ada 6 unit yaitu wheel loader L320 dan L330 dengan kapasitas angkut 5,1 Ton / bucket, kemudian wheel loader Cat 950, Cat 926, Cat 926 dan WA 350 dengan kapasitas angkut 1,9 Ton / bucket. 
Dalam proses operasi dari mesin tersebut pasti mengalami kerusakan dan harus dilakukan perbaikan. Berikut ini data frekuensi kerusakan dan lama perbaikan pada mesin wheel loader pada bulan Januari - Desember 2018 dapat dilihat pada tabel 1 berikut ini.

Tabel 1 Frekuensi Kerusakan Dan Lama Perbaikan Mesin Wheel Loader.

\begin{tabular}{|c|c|c|c|c|c|c|c|}
\hline $\mathrm{Nn}$ & Sub Sintum & 8 & & Mesien & el zowast & & \\
\hline 1 & Extyine & 5 & 7 & 3 & 23 & $\frac{802}{5}$ & 3 \\
\hline 2 & Howhouitic & 12 & 5 & 15 & 6 & 10 & 8 \\
\hline 3 & Tranumixzion & 9 & 6 & 4 & 2 & 5 & 6 \\
\hline 4 & Elentric & 7 & 5 & 4 & 10 & 4 & 3 \\
\hline s & Axles grup & 0 & 0 & 0 & 0 & 2 & 4 \\
\hline 6 & Brate & 5 & 6 & 4 & 3 & 2 & 6 \\
\hline \multicolumn{2}{|c|}{ Frekivensi kertusakan } & 38 & 32 & 31 & 44 & 29 & 30 \\
\hline \multicolumn{2}{|c|}{$\begin{array}{c}\text { Lama perbaikan } \\
\text { (jam) }\end{array}$} & 437 & 398 & 412 & 486 & 290 & 340 \\
\hline
\end{tabular}

Sumber : PT. Swadaya Graha

Berdasarakan tabel 1 frekuensi kerusakan dan lama perbaikan mesin pada bulan Januari Desember 2018, dapat lihat bahwa mesin wheel loader Cat 926 dengan kode Z 04 - 34 memiliki frekuensi kerusakan paling tinggi 44 dan lama perbaikan 486 jam.

Dalam pengoperasian mesin wheel loader pihak PT. Semen Indonesia Tbk mempunyai rencana jam operasional dan target presentase realisasi jam operasional yang harus dicapai dalam tahun 2018. Rencana jam operasional untuk masing - masing wheel loader adalah sebesar $1825 \mathrm{jam} / \mathrm{tahun}$, dengan target presentase dari realisasi jam operasional yang harus dicapai oleh masing - masing wheel loader sebesar $\geq 85 \%$. Berikut ini adalah data rencana dan realisasi jam operasional dari mesin wheel loader dari bulan Januari sampai bulan Desember tahun 2018 dapat dilihat pada tabel 2 sebagai berikut.

Tabel 1.3 Data Rencana Dan Realiasasi Jam Operasional Mesin Wheel Loader Dari Bulan Januari - Desember 2018

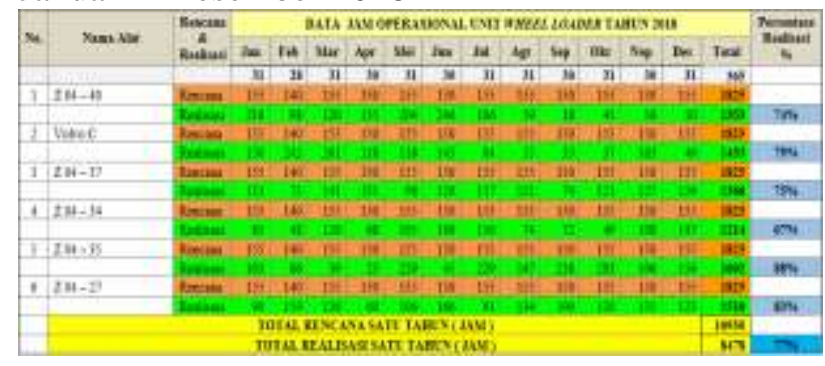

Sumber : PT. Swadaya Graha
Berdasarkan tabel 2 menunjukan bahwa mesin wheel loader Cat 926 dengan kode unit $\mathrm{Z}$ 04 - 34 memiliki persentase realiasasi terendah yaitu $67 \%$ dengan jumlah jam opersional 1214 jam. Total realisasi jumlah jam operasional mesin wheel loader pada tahun 2018 adalah sebesar 8478 dengan persentase realisasi sebesar $77 \%$. Dapat disimpulkan bahwa terdapat permasalahan belum tercapainya target persentase realisasi jam operasional mesin wheel loader 5 dari 6 mesin wheel loader yang telah ditetepkan oleh PT. Semen Indonesia Tbk. Hal ini disebabkan oleh mesin wheel loader mengalami breakdown lama dan kerusakan yang terjadi sewaktu - waktu atau adanya kegiatan perawatan yang tidak terjadwal.

Dari permasalahan yang terjadi, maka penelitian ini mencoba untuk mengetahui mode kegagalan potensi dan efeknya serta penangananya pada mesin wheel loader menggunakan metode FMEA dan mengajukan rencana pemeliharaan menggunakan pendekatan Reability Centered Maintenance (RCM). Dengan metode RCM diharapkan dapat menetapkan penjadwalan perawatan dan dapat mengetahui secara pasti tindakan kegiatan perawatan yang tepat yang harus dilakukan pada setiap komponen mesin wheel loader. Berdasarkan latar belakang di atas, penulis tertarik untuk melakukan penelitian tentang "Perencanaan Penjadwalan Perawatan Mesin Wheel Loader Dengan Pendekatan Reliability Centered Maintenance Di PT. Swadaya Graha”

\section{A. Rumusan Masalah}

Berdasarkan latar belakang tersebut diatas, dapat dirumuskan masalah sebagai berikut: Bagaimana menentukan komponen kritis dan penjadwalan perawatan komponen kritis yang optimal pada mesin wheel loader dengan menggunakan metode Reliability Centered Maintenance di PT. Swadaya Graha?

\section{B. Tujuan Penelitian}

Tujuan dari penelitian ini adalah :

1. Untuk mengetahui kegagalan komponen dan efek dari kegagalan dan menentukan komponen kritis menggunakan metode 
Failure mode and Effect analysis pada mesin wheel loader.

2. Untuk menentukan penjadwalan perawatan yang optimal pada mesin wheel loader dengan menggunakan metode Reliability Centered Maintenance di PT. Swadaya Graha.

3. Untuk menentukan interval waktu perawatan komponen kritis yang optimal.

4. Untuk menentukan usulan tindakan perawatan pada mesin Wheel loader dengan menggunakan Logic Tree Analysis Dan Task Selection .

\section{TINJAUAN PUSTAKA}

\section{A. Perawatan (Maintenance)}

Perawatan didefinisikan sebagai suatu kegiatan merawat fasilitas sehingga fasilitas tersebut berada dalam kondisi siap pakai sesuai dengan kebutuhan. Dengan kata lain, perawatan adalah kegiatan dalam rangka mengupayakan fasilitas produksi berada pada kondisi atau kemampuan produksi yang dikehendaki. Selain itu juga perawatan merupakan suatu kombinasi dari berbagai tindakan yang ditujukan untuk mempertahankan suatu sistem atau memperbaiki dan mengembalikan sistem tersebut pada suatu kondisi yang dikehendaki (Putra, 2011).

\section{B. JENIS TINDAKAN PERAWATAN}

Menurut Putra (2011) Aktivitas dalam maintenance pada umumnya umumnya dibagi menjadi dua kelompok yaitu preventive dan corrective maintenance. Klasifikasi tindakan perawatan dapat dilihat berikut ini.

1. Preventive Maintenance

Preventive maintenance merupakan perawatan yang dilakukan secara terjadwal umumnya secara periodik. Perawatan ini bertujuan untuk mencegah kerusakan, menemukan penyebab kerusakan atau berkurangnya tingkat keandalan peralatan dan menemukan kerusakan tersembunyi. Preventive maintenance terbagi dalam empat kategori tugas yaitu sebagai berikut.
a. Time Directed Maintenance
b. Condition Based Maintenance
c. Failure Finding
d. Run To Failure

\section{Corrective Maintenance}

Kegiatan perbaikan adalah kegiatan perawatan yang dilakukan setelah terjadinya kerusakan atau sistem tidak dapat berfungsi dengan baik. Tindakan yang dapat diambil adalah berupa penggantian komponen (Corrective replacement), perbaikan kecil (repair), dan perbaikan besar (overhaul).

\section{Definisi Kerusakan}

Karakteristik kerusakan pada peralatan umumnya tidak sama meskipun dioperasikan pada waktu yang bersamaan, karakteristik yang sama akan memberikan selang waktu terjadinya kerusakan yang berbeda. Karena kerusakan suatu alat atau komponen tergantung pada variabel waktu dan untuk mengetahui variabel waktu kerusakan digunakan fungsi pada probalitas ( Ansori \& Imron, 2013).

\section{Keandalan (Reliability)}

Menurut Ansori \& Imron (2013), devinisi keandalan adalah sebagai probabilitas komponen, peralatan, mesin atau sistem tetap beroperasi dengan baik sesuai dengan fungsinya yang diharapkan dalam interval waktu dan kondisi tertentu. Dalam teori reliability menurut Tamin (2013) terdapat empat konsep yang dipakai dalam pengukuran tingkat keandalan (reliability) suatu sistem atau produk. Salah satu teori yang akan digunakan dalam penelitian ini adalah

1. Fungsi distribusi kumulatif, pada perawatan adalah probalitis kerusakan yang probalitas terjadinya kerusakan sebelum waktu tertetu, yang secara matematis sebagai berikut:

$$
\left.F(t)=\int_{-\infty}^{t} f t\right) d t
$$

Dimana $\mathrm{F}(\mathrm{t})$ menyatakan distribusi kumulatif, dan jika $\mathrm{t} \rightarrow \infty$, maka $\mathrm{F}(\mathrm{t}) \rightarrow 1$. 


\section{E. Pola Distribusi Data Dalam Keandalan (Reliability)}

Pola distribusi data dalam Keandalan (Reliability) antara lain :

1. Pola Distribusi Weibull fungsi distribusi kumulatif dari distribusi weibull:

$$
F(t)=1 \exp \left[\left(-\frac{t}{\alpha}\right)^{\beta}\right]
$$

2. Pola Distribusi Normal fungsi distribusi kumulatif dari distribusi Normal, sebagai berikut.

$$
f(t)=\frac{1}{\sigma \sqrt{2 \pi}} \exp -\left[\frac{(t-\mu)^{2}}{2 \sigma^{2}}\right]
$$

3. Pola Distribusi Lognormal fungsi distribusi kumulatif dari ditribusi lognormal sebagai berikut ini.

$$
f(t)=\frac{1}{\sqrt{2 \pi \mathrm{t}^{2}} \sigma^{2}} e^{-\frac{1}{2}\left(\frac{1 n t-\mu}{\sigma}\right)^{2}}
$$

4. Pola Distribusi Eksponensial fungsi kumulatif distribusi dari distribusi eksponensial yaitu:

$$
f(t)=1-\lambda \mathrm{e}-\lambda \mathrm{t}
$$

\section{F. Mean Time To Failure}

Rata - rata kerusakan dapat dirumuskan sebagai berikut :

$$
E[T]=\int_{0}^{\infty} t . f .(t) d t
$$

\section{G. Mean Time To Repaire}

MTTR dapat dirumuskan sebagai berikut :

$$
E[T]=\int_{0}^{\infty} R(t) d t
$$

\section{H. Reliability Centered Maintenance (RCM)}

Pengertian Reliability Centered Maintenance (RCM) adalah serangkaian proses yang digunakan untuk menentukan apa yang harus dilakukan dalam memastikan bahwa aset aset fisik dapat berjalan dengan baik dalam menjalankan fungsi yang dikehendaki oleh pemakainya (Ansori \& Imron, 2013).

Dengan menggunakan tujuh pertanyaan tentang aset atau sistem yang diteliti pada dasarnya dapat menulusuri proses RCM ( Ansori \& Imron, 2013).

1. Apakah standart operasional fungsi dan performansi dari asset?
2. Bagaimana kerusakan atau kegagalan aset dalam menjalankan semua fungsinya?

3. Apakah penyebab masing - masing kegagalan fungsi dari aset tersebut?

4. Apakah yang akan terjadi saat aset terjadi kerusakan?

5. Bagaimana masing - masing kerusakan aset tersebut terjadi?

6. Apa yang harus dilakukan untuk memprediksi atau mencegah kerusakan tersebut?

7. Apakah yang dapat dilakukan apabila kegiatan proaktif yang sesuai tidak berhasil diketemukan?

\section{Langkah - Langkah Metode RCM}

Langkah - langkah pada metode Reliability Centered Maintenance (RCM) terdiri dari 7 tahapan ( Aufar dkk, 2014), sebagai berikut :

1. Pemilihan Sistem Dan Pengumpulan Informasi

Hal - hal yang harus diperhatikan dalam pemilihan sistem, antara lain:

a. Sistem memiliki ongkos PM yang tinggi.

b. Sistem memiliki jumlah kegiatan CM yang tinggi selama lebih dari 2 tahun.

c. Sistem memiliki ongkos $\mathrm{CM}$ yang tinggi setelah pemakaian lebih dari 2 tahun.

d. Sistem sudah melewati umur pakai.

e. Sistem memiliki dampak yang tinggi terhadap keselamatan dan keamanan.

2. Definisi Batasan Sistem

Jumlah unit mesin wheel loader di suatu pabrik pasti lebih dari satu maka dari itu, definisi batasan sistem merupakan suatu definisi kasar mengenai sistem atau mesin wheel loader yang akan menjadi fokus penelitian dan batasan yang telah ditetapkan.

3. Deskripsi Sistem Dan Functional Block Diagram

Pendeskripsian sistem penting untuk mengidentifikasi desain sistem yang kritis, hubungan antar komponen dan pengaruhnya terhadap kinerja sistem kemudian hasilnya akan digunakan untuk melakukan perbaikan preventive maintenance. Informasi yang ada kemudian digunakan untuk membuat functional 
block diagram untuk mengidentifikasikan sistem dengan rinci.

4. Penentuan Fungsi Sistem Dan Kegagalan Fungsional

Fungsi sistem ditentukan berdasarkan informasi mengenai jenis kegagalan atau kerusakan yang terjadi pada sistem yang diamati. kegagalan fungsional dapat diartikan sebagai ketidakmampuan suatu peralatan untuk memenuhi fungsinya pada performansi standar yang dapat diterima oleh pengguna.

\section{Failure Mode and Effect Analysis (FMEA)}

FMEA merupakan alat yang digunakan untuk menganalisa keandalan suatu sistem dan penyebab kegagalannya untuk mencapai persyaratan keandalan dan keamanan sistem, desain dan proses dengan memberikan informasi dasar mengenai prediksi keandalan sistem, desain, dan proses (Dyadem Press, 2003). Menentukan peringkat saverity (S), occurrence $(\mathrm{O})$, dan detection (D), untuk masing - masing mode kegagalan dengan skala tingkatan $1-10$.

\section{Logic Tree Analysis (LTA)}

Menurut Utomo (2018) Logic tree analysis merupakan suatu alat pengukuran secara kualitatif yang bertujuan untuk menekan suatu prioritas dan sumber daya yang harus dialokasikan pada setiap mode kegagalan untuk mengklasifikasikan mode kegagalan, karena mode kegagalan tidak dibuat sama. Pada bagian ini komponen terbagi dalam 4 kategori, yakni:

1. Kategori A (Safety problem)

2. Kategori B (Outage problem)

3. Kategori C (Economic problem)

4. Kategori D (Hidden failure)

\section{Task selection}

Menurut Rachman (2013) Task selection dilakukan untuk menentukan kebijakan yang paling mungkin untuk diterapkan dan memilih task yang efektif untuk setiap mode kegagalan yang ada. Pada proses task selection ini dilakukan penentuan hubungan kegagalan dengan jenis task yang ada apakah kegagalan yang ada berhubungan langsung dengan time directed
(TD), condition directed (CD), dan failure finding (FF) serta Run to Failure (R.T.F).

\section{J. Perhitungan Total Minimum Downtime}

Perhitungan total minimum downtime, yang bertujuan untuk menentukan penggantian atau perawatan yang optimal berdasarkan interval waktu, tp. Diantara penggantian preventive dengan menggunakan kriteria minimum downtime per - unit yaitu :

$$
\mathrm{D}(\mathrm{tp})=\frac{H(t p) T f+T p}{t p+T p}
$$

Dengan meminimumkan total downtime, diperoleh tindakan penggantian komponen berdasarkan waktu tp yang optimal. Untuk komponen yang memiliki ditribusi kegagalan mengikuti peluang tertentu dengan fungsi peluang $f(t)$, maka nilai harapan banyaknya kegagalan yang terjadi dalam interval waktu $(0$, tp) dapat dihitung sebagai berikut :

$$
H(t p)=\sum_{i=0}^{t p-1}(1+H(t p-1-i)) \int_{i}^{i+1} f(t) d t
$$

$\mathrm{H}(0)$ ditetepkan sama dengan nol, sehingga untuk tp $=0$, maka $\mathrm{H}(\mathrm{tp})=\mathrm{H}(0)=0$ Syahroni $(2017)$.

\section{METODELOGI PENELITIAN}

Dalam penelitian ini langkah awal adalah melakukan observasi dilapangan untuk mengidentifikasi permasalahan yang terjadi dilakukan perumusan masalah dan penentuan tujuan penelitian, dalam penelitian ini metode yang digunakan adalah Reliability Centered Maintenance. Lebih jelasnya dapat dilihat dalam gambar 1 flowchart penelitian. 




Gambar 1 Flowchart Penelitian

Metode ini terdiri dari 7 langkah, yakni seleksi sistem dan pengumpulan informasi, pendefinisian batasan sistem, deskripsi sistem, fungsi sistem dan kegagalan fungsi, Failure mode and Effect Analysis (FMEA), Logic Tree Analysis (LTA), dan pemilihan tindakan, perhitungan nilai MTTR dan MTTF. Kemudian jadwal perawatan komponen kritis diperoleh berdasarkan perhitungan waktu Total Minimum Downtime (TMD).

\section{HASIL DAN PEMBAHASAN}

A. Pengumpulan data

Berdasarkan hasil pengumpulan data, maka sistem yang dipilih adalah sistem yang memiliki kriteria total frekuensi kerusakan dan downtime terbesar yang ditunjukkan pada tabel 3 .
Tabel 3 Data Downtime Mesin Wheel Loader tahun 2018

\begin{tabular}{|c|c|c|c|c|c|}
\hline Kode Unit & $\begin{array}{c}\text { Perbaikan } \\
\text { (jam) }\end{array}$ & $\begin{array}{c}\text { Service } \\
\text { Berkala } \\
\text { (jam) }\end{array}$ & $\begin{array}{c}\text { Operasionai } \\
\text { Mesin } \\
\text { (han) }\end{array}$ & $\begin{array}{c}\text { Set Up } \\
\text { Mesin } \\
\text { (jam) }\end{array}$ & Donotrane \\
\hline WL Z 04-40 & 437 & 9 & 237 & 59,25 & 505,25 \\
\hline WL Volvo C & 398 & 7 & 274 & 70,75 & 475,75 \\
\hline WL Z 04-27 & 412 & 7,5 & 290 & 72,5 & 501 \\
\hline WL Z 04-34 & 486 & 9 & 250 & 62,5 & 557,5 \\
\hline WL Z 04-35 & 290 & 14,5 & 302 & 14,5 & 379,75 \\
\hline WL Z 04-37 & 340 & 15 & 294 & 73,5 & 428,5 \\
\hline Jumlah & 2363 & 62 & 1647 & 353 & 2847,75 \\
\hline
\end{tabular}

Sumber : PT. Swadaya Graha

Berdasarkan tabel 3 dapat dilihat bahwa mesin dengan kode WL Z 04 - 34 memiliki total downtime terbesar yaitu 557, 5 jam, karena mesin WL Z 04 - 34 dipilih dalam penelitian ini.

\section{B. Pengolahan data}

1. Penjelasan sistem dan fungsional block diagram.

Wheel loader merupakan jenis alat berat pemuat material hasil dari galian tambang yang tidak dapat langsung dipindahkan kealat angkut ataupun alat lainnya. wheel loader juga dapat difungsikan sebagai alat pengerjaan pada umumnya mulai dari cleaning ringan, menggusur, ataupun menggali dangkal dan menunjang operasional produksi pada PT. Semen indonesia. Mesin wheel loader terdiri dari $6 \mathrm{sub}$ sistem yaitu :

a. Engine yang berfungis sebagai penggerak utama pada sistem atau menjadi bagian yang paling penting dari unit mesin wheel loader. Engine akan menggerakan sub sistem lainnnya seperti transmission, axle group, hydroulic, brake dan electric.

b. Transmission yang berfungsi sebagai pengatur kecepatan gerak, torsi, serta arah sehingga unit atau mesin dapat bergerak maju ataupun mundur. Kemudian juga sebagai penghubung putaran flywheel dari kopling ke poros propeller shaff.

c. Axle group yang berfungsi sebagai penggerak roda.

d. Hydroulic yang berfungsi sebagai penggerak cylinder boom dan cylinder tilt untuk menggerakan bucket yang bertujuan untuk melakukan loading material.

e. Brake yang berfungsi untuk memperlambat dan menghentikan perputaran roda agar laju 
mesin wheel loader menjadi pelan atau berhenti.

f. Electric yang berfungsi sebagai sistem kelistrikan pada lampu operasional dan starter yang berguna untuk menyalakan mesin wheel laoder.

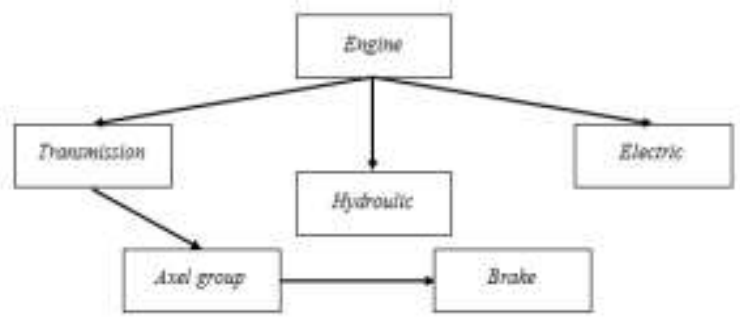

Gambar 2. Fungsional Block Diagram

Pada gambar 2 merupakan diagram blok fungsi dari mesin wheel loader dengan kode unit Z 04 -34.

2. Identifikasi Fungsi Sub Sistem Dan

Kegagalan Fungsional

Berdasarkan hasil brainstorming dengan team FMEA dilakukan identifikasi fungsi sub sistem dan kegagalan fungsional yang terjadi pada sistem yang diteliti. Hasil dari identifikasi kegagalan fungsional dapat dilihat pada tabel 4.

Tabel 4 Fungsi Sub Sistem dan Kegagalan

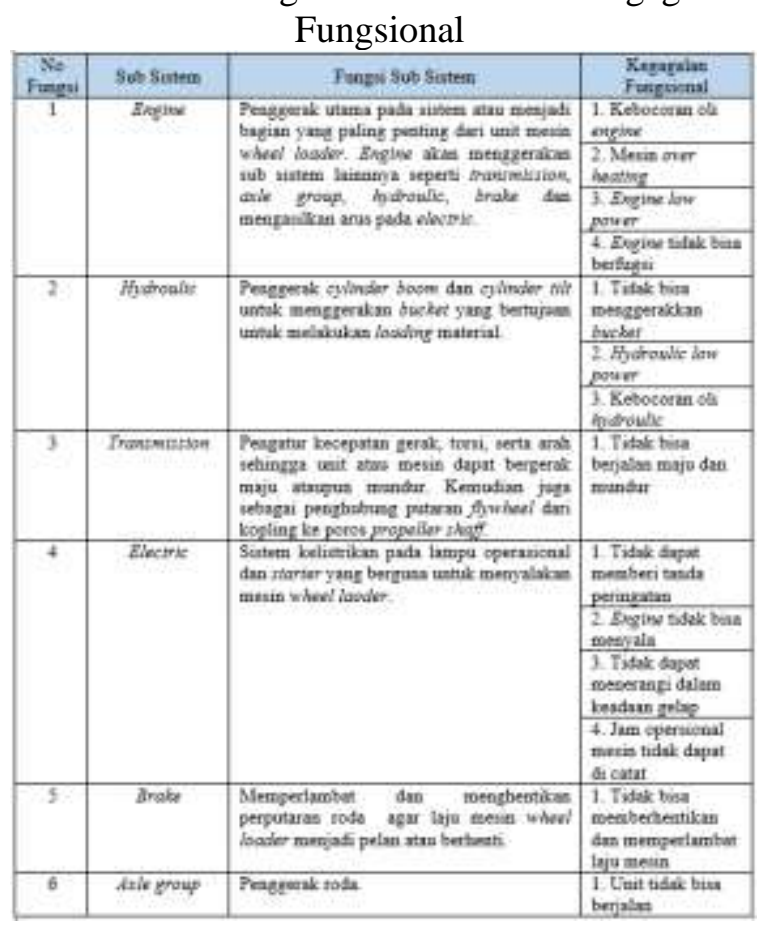

3. Penentuan Nilai Saverity, Occurrence, Detection Dan Perhitungan Nilai RPN
Failure Mode and Effect Analysis (FMEA) merupakan proses mengidentidikasi kegagalan dari suatu komponen yang dapat menyebabkan kegagalan fungsi dari sistem. Penerapan FMEA dilakukan terlebih dahulu dengan mencari nilai severity, occurance, dan detection. Penentuan nilai severity, occurance, dan detection dengan team FMEA mulai dari Koord maint dan mekanik mesin wheel loader. Tahap selanjutnya yang dilakukan setelah nilai severity, occurance, dan detection didapatkan adalah komponen yang akan dipilih adalah dengan 4 nilai RPN tertinggi untuk dilakukan penjadwalan perawatan mesin wheel loader. Berdasarkan hasil proses FMEA setelah dilakukan perhitungan RPN dapat diketahui komponen yang memiliki mode kegagalan dengan resiko tinggi. Komponen tersebut dapat dilihat pada tabel 5 berikut ini. 
Tabel 5 Fairlure Mode and Effect Analysis (FMEA)

\begin{tabular}{|c|c|c|c|c|c|c|c|c|c|c|}
\hline No & $\begin{array}{c}\text { Sub } \\
\text { Sistem }\end{array}$ & Fungsi & $\begin{array}{l}\text { Kegagalan } \\
\text { Fumgsi }\end{array}$ & $\begin{array}{c}\text { Mode } \\
\text { Kegagalan }\end{array}$ & $\begin{array}{c}\text { Penyebab Mode } \\
\text { Kegagalan }\end{array}$ & $\begin{array}{c}\text { Dampak } \\
\text { Kegagalan }\end{array}$ & $\mathrm{s}$ & O & D & RPN \\
\hline 1 & Hydroulict & $\begin{array}{l}\text { Penggerak cylinder boom } \\
\text { dan cylinder tilt untuk } \\
\text { menggerakan bucket yang } \\
\text { bertujuan untuk melakukan } \\
\text { loading material }\end{array}$ & $\begin{array}{l}\text { Hydroulic } \\
\text { low power }\end{array}$ & $\begin{array}{l}\text { Hydroulic } \\
\text { pump rusak }\end{array}$ & $\begin{array}{l}\text { Kekurangan oli } \\
\text { atau pemakaian } \\
\text { tidak sesuai SOP }\end{array}$ & $\begin{array}{l}\text { Tidak ada oil } \\
\text { indroulic yang } \\
\text { disalukan } \\
\text { cyinder boom dan } \\
\text { cylinder tilt }\end{array}$ & 9 & 3 & 6 & 162 \\
\hline 2 & \multirow{3}{*}{ Engine } & \multirow{3}{*}{$\begin{array}{l}\text { Penggerak utama pada } \\
\text { sistem atau menjadi bagian } \\
\text { yang paling penting dari } \\
\text { unit mesin wheel loader. } \\
\text { Engine akan menggerakan } \\
\text { sub sistem lainmnya seperti } \\
\text { transmission, arle group. } \\
\text { hodroulic. brake dan } \\
\text { electric. }\end{array}$} & $\begin{array}{l}\text { Engine low } \\
\text { power }\end{array}$ & $\begin{array}{l}\text { Kebocoran } \\
\text { kompresi } \\
\text { mesin }\end{array}$ & $\begin{array}{l}\text { Ring Seker aus } \\
\text { dan } \quad \text { keausan } \\
\text { dinding cylinder }\end{array}$ & $\begin{array}{l}\text { Ruang pembakaran } \\
\text { tidak bekerja secara } \\
\text { optimal sehingga } \\
\text { tenaga yang } \\
\text { dihasilkan kecil }\end{array}$ & 7 & 3 & 7 & 147 \\
\hline 3 & & & $\begin{array}{l}\text { Engine over } \\
\text { heating }\end{array}$ & $\begin{array}{l}\text { Radiator } \\
\text { bocor }\end{array}$ & $\begin{array}{l}\text { Terjadi benturan } \\
\text { atan temperatur } \\
\text { air tinggi }\end{array}$ & $\begin{array}{l}\text { Proses pendinginan } \\
\text { engine gagal }\end{array}$ & 4 & 6 & 5 & 120 \\
\hline 4 & & & $\begin{array}{l}\text { Engine tidak } \\
\text { bisa } \\
\text { menyala }\end{array}$ & $\begin{array}{l}\text { Boscpump } \\
\text { bocor dan } \\
\text { macet }\end{array}$ & Seal rusak & $\begin{array}{l}\text { Supply bahan bakar } \\
\text { ke seker tidak ada }\end{array}$ & 7 & 4 & 4 & 112 \\
\hline
\end{tabular}

4. Logic Tree Analysis Dan Task Selection

Penyusunan Logic Tree Analysis ( LTA ) merupakan proses kualitatif yang digunakan untuk mengetahui konsekuensi yang ditimbulkan oleh masing - masing mode kegagalan yang terjadi. Pada tahap ini dilakukan brainstrorming dengan karyawan dari PT. Swadaya Graha dengan masa kerja lebih dari 5 tahun dan paham mengenai mesin wheel loader. Tujuan dari Logic Tree Analysis adalah mengklasifikasikan mode kegagalan ke dalam beberapa kategori sehingga dapat ditentukan tingakat prioritas dalam penanganan masing - masing mode kegagalan berdasarkan kategorinya. Pada gambar 3 dapat dilihat struktur pertanyaan pada Logic Tree Analysis (LTA) sebagai berikut ini.

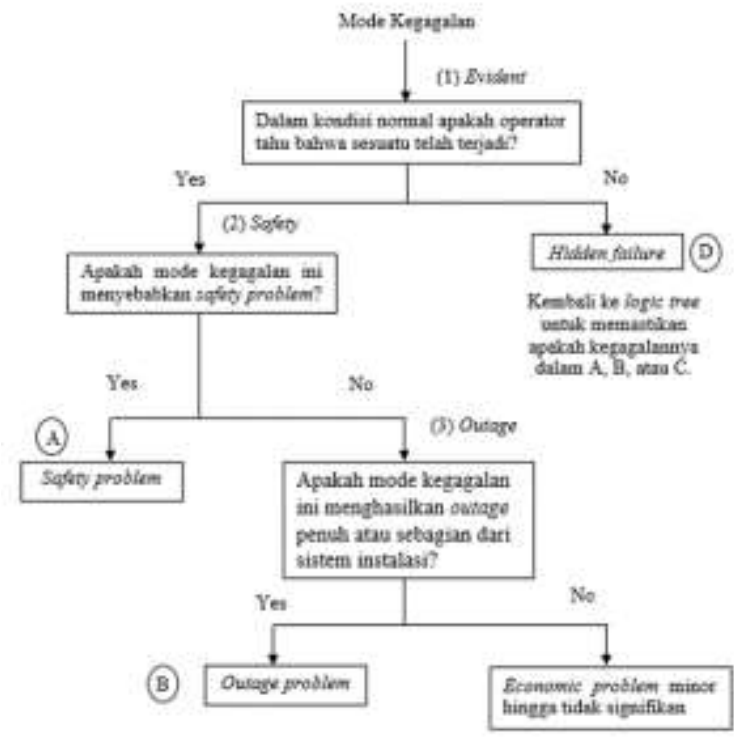

Gambar 3 Struktur Pertanyaan LTA

Berikut ini tabel analisis Logic Tree Analysis pada mode kegagalan yang terjadi pada 4 komponen yang memiliki resiko paling tinggi pada mesin wheel laoder Z $04-34$ dapat dilihat pada tabel 6 berikut ini.

Tabel 6 Analisis Logic Tree Analysis (LTA)

\begin{tabular}{|c|c|c|c|c|c|c|c|}
\hline \multirow{2}{*}{ No } & \multirow{2}{*}{ Sub Sistem } & \multirow{2}{*}{ Komponen } & \multirow{2}{*}{$\begin{array}{c}\text { Mode } \\
\text { Kegagalan }\end{array}$} & \multicolumn{4}{|c|}{ Criticality Analysis } \\
\hline & & & & Evident & Safety & Outage & Kategory \\
\hline 1 & Hydroulict & Pump hydroulic & Hydroulic pump rusak & $\mathrm{Y}$ & $\mathrm{Y}$ & $\mathrm{N}$ & A \\
\hline 2 & & Radiator & Radiator bocor & $\mathrm{Y}$ & $\mathrm{Y}$ & $\mathrm{N}$ & $\mathrm{A}$ \\
\hline 3 & Engine & Block engine & Kebocoran kompresi mesin & $\mathrm{Y}$ & $\mathrm{N}$ & $\mathrm{Y}$ & $\mathrm{B}$ \\
\hline 4 & & Bostpump & Boscpump bocor & $\mathrm{Y}$ & $\mathrm{N}$ & $\mathrm{Y}$ & $\mathrm{B}$ \\
\hline
\end{tabular}

Kategori mode kegagalan dalam identifikasi yang telah dilakukan dengan logic tree analisis sebagai berikut ini.

1. Kategori A (Safety problem) dengan mode kegagalan Radiator bocor dan Hydroulic pump rusak.

2. Kategori B (Outage problem) dengan mode kegagalan Kebocoran kompresi mesin dan Bostpump bocor. 
Pemilihan tindakan merupakan tahap selanjutnya dalam proses Reliability Centered Maintenance. Proses ini akan menentukan tindakan yang tepat untuk masing - masing komponen. Pada tahap ini dilakukan brainstrorming dengan karyawan dari PT. Swadaya Graha dengan masa kerja lebih dari 5 tahun dan paham mengenai mesin wheel loader.

Beberapa kategori tindakan pencegahan tersebut antara lain:

1. Condition Directed (CD) adalah tindakan yang diambil yang bertujuan untuk mendeteksi. Apabila ada pendeteksian ditemukan gejalagejala kerusakan komponen maka dilanjutkan dengan perbaikan atau penggantian komponen.

2. Time Directed (TD) adalah tindakan yang diambil yang lebih berfokus pada aktivitas pembersihan yang dilakukan secara berkala.

3. Finding Failure (FF) adalah tindakan yang diambil dengan tujuan untuk menemukan kerusakan peralatan yang tersembunyi dengan pemeriksaan berkala.

Berikut ini adalah struktur pemilihan tindakan yang tepat terhadap komponen mesin wheel loader dapat dilihat pada gambar 4 berikut:

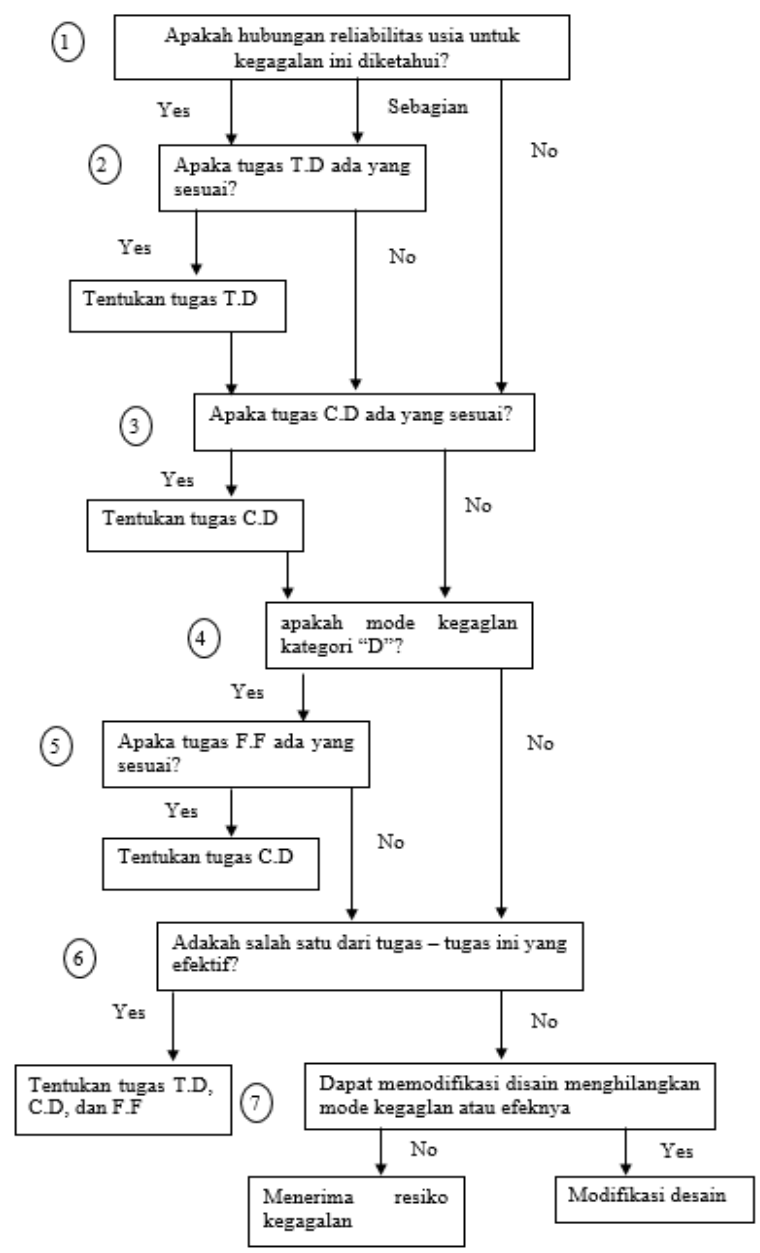

Gambar 4 Struktur Pemilihan Tindakan

Berikut ini tabel pemilihan tindakan pada 4 komponen yang memiliki resiko paling tinggi pada mesin wheel laoder Z 04 - 34 dapat dilihat pada tabel 7 berikut ini.

Tabel 7 Pemilihan Tindakan

\begin{tabular}{|c|l|l|c|c|c|c|c|c|c|c|}
\hline \multirow{2}{*}{ No } & \multirow{2}{*}{ Sub Sistem } & \multicolumn{2}{|c|}{ Mode Kegagalan } & \multicolumn{4}{|c|}{ Selection Guide } & \multirow{2}{*}{ Jenis } \\
\cline { 4 - 10 } & & & 1 & 2 & 3 & 4 & 5 & 6 & 7 & Tindakan \\
\hline 1 & Hydroulict & Hydroulic pump rusak & $\mathrm{Y}$ & $\mathrm{N}$ & $\mathrm{Y}$ & $\mathrm{N}$ & $\mathrm{Y}$ & $\mathrm{Y}$ & - & (C.D) \\
\hline 2 & Engine & Radiator bocor & $\mathrm{Y}$ & $\mathrm{N}$ & $\mathrm{Y}$ & $\mathrm{N}$ & $\mathrm{Y}$ & $\mathrm{Y}$ & - & (C.D) \\
\hline 3 & & Kebocoran kompresi mesin & $\mathrm{Y}$ & $\mathrm{N}$ & $\mathrm{Y}$ & $\mathrm{N}$ & $\mathrm{Y}$ & $\mathrm{Y}$ & - & (C.D) \\
\hline 4 & & Boscpump bocor & $\mathrm{Y}$ & $\mathrm{N}$ & $\mathrm{Y}$ & $\mathrm{N}$ & $\mathrm{Y}$ & $\mathrm{Y}$ & - & (C.D) \\
\hline
\end{tabular}

Pemilihan tindakan pencegahan berdasarkan hasil analisis terhadap FMEA dan LTA adalah sebagai berikut:

1. Condition Directed (C.D)

Komponen - komponennya antara lain :
a. Hydroulic pump
b. Radiator
c. Block engine
d. Bostpump

5. Perhitungan MTTF dan MTTR

Tahapan selanjutnya adalah menentukan penjadwalan perawatan terhadap 4 komponen kritis yang mempunnyai resiko tinggi berdasarkan nilai
RPN ( Riks Prioritas Number ) pada FMEA. Tetapi sebelumnya harus diketahui terlebih dahulu distribusi waktu antar kerusakan dan distribusi lama perbaikan tiap komponen kritis. Komponen ktitis tersebut adalah Pump Hydroulic, Block engine, Radiator dan Bostpump. Data waktu antar kerusakan diperoleh dari waktu selesai perbaikan kerusakan yang pertama sampai waktu kerusakan berikutnya. Sedangkan data waktu lama perbaikan diperoleh berdasarkan lamanya waktu perbaikan saat kerusakan terjadi. Setelah dilakukan perhitungan dengan menggunkan software minitab 16 dari 4 komponen kritis. Berikut ini adalah 
nilai MTTF dan MTTR pada komponen kritis dapat dilihat dalam tabel 8 berikut ini.

Tabel 8 Nilai MTTF dan MTTR

\begin{tabular}{|c|c|c|c|c|}
\hline Komporen & Unima & \multicolumn{2}{|c|}{ Peas-tata ( $\mu$ dibagi 8 jem $)$} & $\begin{array}{l}\text { Standact Deviasi (o } \\
\text { dibsy } 8 \text { jan) }\end{array}$ \\
\hline \multirow[b]{2}{*}{$\begin{array}{l}\text { Puatp } \\
\text { Hydrouilic }\end{array}$} & Downกime & MTIR & 26,2 jeni $=3,27$ hari & 39,5 jeer $=4,93$ hani \\
\hline & $\begin{array}{l}\text { Iexterval waktu } \\
\text { kerusaban }\end{array}$ & MTIF & $742 \mathrm{jman}-92,75$ hari & 627 jami $-78,37$ hact \\
\hline \multirow[b]{2}{*}{ Block engine } & Downtime & TTR & 77 havi & 14,44 jum $=1.8$ hart \\
\hline & $\begin{array}{l}\text { Interval waktu } \\
\text { kerusaban }\end{array}$ & MrTF & 531 jeas $=66,37$ hari & 250,29 jien $=32,4$ hari \\
\hline \multirow[t]{2}{*}{ Radiator } & Dowrnime & TIR & $9.88 \mathrm{j}$ & 7.14 jear $=0.89$ haei \\
\hline & $\begin{array}{l}\text { Interval waltu } \\
\text { kerusakan }\end{array}$ & MTIF & $583 \mathrm{jman}=72,8$ taei & 2284 jam $=285$, Stanei \\
\hline \multirow[t]{2}{*}{ Bostpanp } & Donerisine & MTTR & 0,25 jent $=1,15$ hase & 7,27 jen $=0,9$ hast \\
\hline & $\begin{array}{l}\text { Interval walthi } \\
\text { kerusakan }\end{array}$ & MTIF & $647,25 \mathrm{jmm}=80,9 \mathrm{hmi}$ & $\begin{array}{l}219,64 \text { jant }=27,45 \\
\text { hari }\end{array}$ \\
\hline
\end{tabular}

6. Perhitungan Total Minimum Downtime

Berdasarkan data parameter distribusi komponen pada Tabel 8 akan ditentukan total minimum downtime (TMD) sebagai interval waktu penjadwalan perawatan komponen dengan downtime terkecil. Waktu yang diperlukan untuk mengganti komponen karena terjadi kerusakan disimbolkan dengan Tf, dan waktu yang diperlukan untuk mengganti komponen berdasarkan interval waktu (tindakan preventif) disimbolkan sebagai Tp. Nilai Tf dan Tp dari masingmasing komponen kritis diambil dari hasil perhitungan MTTR dapat dilihat pada Tabel 9 berikut:

Tabel 9 Parameter Distribusi Dan Lama Perbaikan

\begin{tabular}{|l|l|l|l|l|}
\hline No & \multicolumn{1}{|c|}{ Komponen } & \multicolumn{1}{c|}{ Parameter } & \multicolumn{1}{c|}{ If } & \multicolumn{1}{c|}{ Tp } \\
\hline 1 & Plamp fydroulic & $\mu=26,2 \sigma=39,5$ & 3,27 & 3,27 \\
\hline 2 & Block engine & $\mu=22,17 \sigma=14,44$ & 2.77 & 2.77 \\
\hline 3 & Radiator & $\mu=9,88 \sigma=7,14$ & 1,23 & 1,23 \\
\hline 4 & Bostpump & $\mu=9,25 \sigma=7,27$ & 1,15 & 1,15 \\
\hline
\end{tabular}

Selanjunya dilakukan perhitungan total minimum downtime sebagai interval perawatan komponen kritis untuk mengetahui downtime paling minimum dari interval perawatan. Komponen pump Hydroulic diambil sebagai contoh perhitungan total minimum downtime dengan langkah langkah:

a. Menentukan nilai fungsi distribusi kumulatif pada komponen pump hydroulic. Berikut ini adalah perhitungannya :

Jenis distribusi : lognormal

Parameter $\quad: \mu=26,2 \sigma=39,5 \pi=3,14$

Fungsi ditribusi kumulatif untuk lognormal adalah :

$$
f(t)=\frac{t}{\sqrt{2 \pi t^{2}} 39,5^{2}} e^{-\frac{1}{2}\left(\frac{\ln t-26,2}{39,5}\right)^{2}}
$$

$$
\begin{gathered}
f(1)=\frac{1}{\sqrt{2 \pi 1^{2}} 39,5^{2}} e^{-\frac{1}{2}\left(\frac{\ln 1-26,2}{39,5}\right)^{2}} \\
=0,253572055 \\
f(2)=\frac{2}{\sqrt{2 \pi 2^{2}} 39,5^{2}} e^{-\frac{1}{2}\left(\frac{\ln 2-26,2}{39,5}\right)^{2}} \\
=0,259222869
\end{gathered}
$$

Dan seturusnya sampai $\mathrm{f}(92)$ dan hasil perhitungan diperoleh dengan menggunakan Microsoft Excel 2013.

b. Perhitungan banyaknya kerusakan komponen pada interval waktu $(0$, tp) pada komponen Pump Hydroulic yaitu sebagai berikut:

$$
\begin{aligned}
\mathrm{H}(0) & =\text { selalu ditetapkan } \mathrm{H}(0)=0 \\
\mathrm{H}(1) & =[1+\mathrm{H}(0)] \times \mathrm{F}(1) \\
& =[1+0] \times 0,253572055=0,253572055 \\
\mathrm{H}(2) & =[1+\mathrm{H}(1)] \times \mathrm{F}(2) \\
& =[1+(0,253572055)] \times 0,259222869 \\
& =0,324954544
\end{aligned}
$$

Dengan rumus yang sama untuk hasil perhitungan $\mathrm{H}(3), \mathrm{H}(4), \ldots \ldots . . \mathrm{H}(\mathrm{t})$ hasil perhitungan diperoleh menggunakan Microsoft Excel 2013.

c. Perhitungan Total minimum downtime pada komponen Pump Hydroulic yaitu:

$$
\begin{aligned}
& \mathrm{D}(\mathrm{tp})=\frac{H(t p) T f+T p}{t p+T p} \\
& \mathrm{D}(\mathrm{tp}=1)=\mathrm{D}(1) \\
& =\frac{(0,253572055)(3,27)+(3,27)}{1+3,27} \\
& =1,59 \text { hari } \\
& \mathrm{D}(\mathrm{tp}=2)=\mathrm{D}(2) \\
& =\frac{(0,324954544)(3,27)+(3,27)}{1+3,27} \\
& =1,68 \text { hari }
\end{aligned}
$$

\begin{tabular}{|c|c|c|c|c|c|}
\hline No & Kamponen & $t$ & IIt & III & $\mathrm{Dt}$ \\
\hline 1 & Punp bivadrowlic & 52 & 0,286629044 & 0,401662164 & 1,372599379 \\
\hline 2 & Black engine & 58 & 0,1048994 & 0,1171596 & 0,3701137 \\
\hline 3 & Radiontor & 18 & 0,163804929 & 0,195339053 & $0,30422959.4$ \\
\hline 4 & Bostpump & 16 & 0,186470441 & 0,228385381 & 0,329698581 \\
\hline
\end{tabular}

Keterangan :

Untuk hasil perhitungan $\mathrm{D}(3), \mathrm{D}(4)$

komponen Pump Hydroulic hasil perhitungan diperoleh menggunakan Microsoft Excel 2013.

Berdasarkan perhitungan Total Minimum Downtim dari komponen Pump Hydroulic, Block engine, Radiator dan Bostpump, maka diperoleh interval perawatan yang optimum untuk masingmasing komponen pada Tabel 10.

Tabel 10 Rekapitulasi Interval Perawatan 
Dari tabel 10 dapat dilihat bahwa interval perawatan / penjadwalan peratan optimum untuk komponen pump hydroulic yaitu setiap 52 hari, untuk komponen block cylinder setiap hari 58, untuk komponen radiator setiap 18 hari, untuk komponen bostpump setiap 16 hari. Adapun tujuan dari penjadwalan perawatan dari komponen tersebut adalah untuk menjaga agar mesin tetap dalam keadaan siap untuk di operasikan agar tetap dapat menjalankan proses produksi dengan baik.

\section{Kesimpulan}

Dari hasil penelitian ini didapatkan kesimpulan sebagai berikut:

1. Dari hasil pengolahan data dengan metode FMEA maka didapatkan mode kegagalan / kerusakan yang terjadi dan efek kegagalan dari mesin wheel loader Z 04 - 34 sebanyak 28 kegagalan / kerusakan. Kemudian diketahui ada 4 komponen yang memiliki resiko kegagalan paling tinggi / nilai RPN yang tinggi yaitu, Pump Hydroulic dengan nilai RPN 162, Block Engine dengan nilai RPN 147, Radiator dengan nilai RPN 120 dan Bostpump dengan nilai RPN 112.

2. Setelah melalui semua tahapan pada metode RCM didapatkan penjadwalan perawatan mesin wheel loader yang optimal dengan perhitungan Total Minimum Downtime terhadap 4 komponen kritis yaitu sebagai berikut:
a. komponen Pump Hydroulic 52 hari.
b. komponen Block Engine 58 hari.
c. komponen Radiator 18 hari.
d. komponen Bostpump 16 hari

3. Hasil perhitungan MTTR dan MTTF untuk menentukan waktu interval perawatan komponen kritis yaitu:

a. Pump Hydroulic, hasil perhitungan MTTF dengan 742 jam atau rata - rata sama dengan 92 hari untuk hasil perhitungan MTTR dengan 26 jam atau rata - rata sama dengan 3 hari.

b. Block engine, hasil perhitungan MTTF dengan 531 jam atau rata - rata sama dengan 66 hari untuk hasil perhitungan MTTR dengan 22 jam atau rata - rata sama dengan 3 hari. c. Radiator, hasil perhitungan MTTF dengan 538 jam atau rata - rata sama dengan 73 hari untuk hasil perhitungan MTTR dengan 9,88 jam atau rata - rata sama dengan 1 hari.

d. Bostpump, hasil perhitungan MTTF dengan 647 jam atau rata - rata sama dengan 81 hari untuk hasil perhitungan MTTR dengan 9,25 jam atau rata - rata sama dengan 1 hari.

4. Rekomendasi tindakan yang tepat melalui metode Logic Tree Analisis (LTA) dan Task selection adalah

a. komponen Pump Hydroulic masuk dalam categori A (safety problem) dengan pemilihan tindakan yaitu CD/ Conditional Direted.

b. Komponen Block Engine masuk dalam categori B (Outage problem) dengan pemilihan tindakan yaitu $\mathrm{CD} /$ Conditional Direted.

c. Komponen Radiator masuk dalam Kategori A (safety problem) dengan pemilihan tindakan yaitu $\mathrm{CD} /$ Conditional Direted.

d. Komponen Bostpump masuk dalam kategori B (outage problem) dengan pemilihan tindakan yaitu $\mathrm{CD} /$ Conditional Direted.

\section{DAFTAR PUSTAKA}

Ansori, N., Mustajib, M, I. 2013. Sistem Perawatan Terpadu. Yogyakarta : Graha Ilmu.

Aufar, A. N., Leksananto, K., \& Prassetiyo, H. (2014). Usulan Kebijakan Perawatan Area Produksi Trim Chassis dengan Menggunakan Metode Reliability Centered Maintenance (Studi Kasus: PT. Nissan Motor Indonesia). Reka Integra, 2(4).

Denur, D., Hakim, L., Hasan, I., \& Rahmad, S. (2017). Penerapan Reliability Centered Maintenance (RCM) pada Mesin Ripple Mill. JISI: Jurnal Integrasi Sistem Industri, 4(1), 27-34.

Dyadem Press. 2003. Guidelines for Failure Mode and Effect Analysis for Automotive, Aerosapce and General Manufacturing Industries. Ontario: CRC Press. 
Putra, Eko Lisysantaka Rusma. 2011. Artikel Reliability Centered Maintenance (RCM) https://www.scribd.com (diakses pada tanggal 26 april 2019).

Syahroni, Ikhwan. 2017. Usulan Perencanaan Perawatan Mesin Forklif Dengan Metode Relability Centered Maintenance Di PT. Indospring Tbk. Sekripsi. Universitas Muhammadiyah Gresik.

Rachman, H., Garside, A. K., \& Kholik, H. M. (2017). Usulan Perawatan Sistem Boiler Dengan Metode Reliability Centered Maintenance (RCM). Jurnal Teknik Industri, 18(1), 8693.

Hidayat, H., Jufriyanto, M., \& Rizqi, A. (2021). Perancangan RCM (Reliability Centered Maintenance) Untuk Mengurangi Downtime Mesin Pembuat Botol (Studi Kasus PT IGLAS (Persero), Gresik). MATRIK : Jurnal Manajemen Dan
Teknik Industri Produksi, 21(2), 157 164. doi:10.30587/matrik.v21i2.2038

Hidayat, H., Jufriyanto, M., \& Rizqi, A. (2020). ANALISIS OVERALL EQUIPMENT EFFECTIVENESS (OEE) PADA MESIN CNC CUTTING. ROTOR, 13(2), 61-66. doi:10.19184/rotor.v13i2.20674

Tamin, W., Sinaga, T. S., Rambe, M., \& Jabbar, A. (2013). Penerapan Preventive Maintenance Dengan Menggunakan Metode Reliability Centered Maintenance Dengan Mengaplikasikan Grey Fmea Pada PT. Wxy. Jurnal Teknik Industri USU, 1(3).

Utomo, R. W. (2018). Perencanaan Perawatan Mesin Pump 107 Dengan Metode Reability Centered Maintenance (RCM) di PT. Petrokimia Gresik. Jurnal Energi dan Teknologi Manufaktur (JETM), 1(02), 3338. 